Dear Author,

Please, note that changes made to the HTML content will be added to the article before publication, but are not reflected in this PDF.

Note also that this file should not be used for submitting corrections. 
Note

\title{
Colony size-frequency distribution of pocilloporid juvenile corals along a natural environmental gradient in the Red Sea
}

\author{
Diego F. Lozano-Cortés ${ }^{a, b, *}$, Michael L. Berumen ${ }^{a}$ \\ a Division of Biological and Environmental Sciences and Engineering, Red Sea Research Center, King Abdullah University of Science and Technology, Thuwal, 23955, Saudi Arabia \\ ${ }^{b}$ Coral Reef Ecology Research Group, Department of Biology, Universidad del Valle, A.A. 25360, Cali, Colombia
}

\section{A R T I C L E I N F O}

\section{Article history:}

Received 4 May 2015

Received in revised form 16 October 2015

Accepted 22 October 2015

Available online $\mathrm{xxxx}$

\section{Keywords:}

Algae

Coral reefs

Demographics

Juvenile corals

Parrotfish

Red Sea

\begin{abstract}
A B S T R A C T
Coral colony size-frequency distributions can be used to assess population responses to local environmental con- 21 ditions and disturbances. In this study, we surveyed juvenile pocilloporids, herbivorous fish densities, and algal 22 cover in the central and southern Saudi Arabian Red Sea. We sampled nine reefs with different disturbance his- 23 tories along a north-south natural gradient of physicochemical conditions (higher salinity and wider tempera- 24 ture fluctuations in the north, and higher turbidity and productivity in the south). Since coral populations with 25 negatively skewed size-frequency distributions have been associated with unfavorable environmental condi- 26 tions, we expected to find more negative distributions in the southern Red Sea, where corals are potentially 27 experiencing suboptimal conditions. Although juvenile coral and parrotfish densities differed significantly be- 28 tween the two regions, mean colony size and size-frequency distributions did not. Results suggest that 29 pocilloporid colony size-frequency distribution may not be an accurate indicator of differences in biological or 30 oceanographic conditions in the Red Sea.
\end{abstract}

(c) 2015 Published by Elsevier Ltd.

\section{Introduction}

A key mechanism by which coral reef ecosystems are capable of recovering from natural or anthropogenic disturbances is their ability to replenish their populations through the successful recruitment of new individuals (Bak and Engel, 1979; Caley et al., 1996). The establishment and survival of juvenile corals are indicative of good conditions for the development and growth of corals, and consequently highlight the importance of studying demographic processes (Dunstan and Johnson, 1998; Babcock et al., 2003). Although many factors may influence recruitment and colonization patterns of reef organisms (Burt et al., 2009; Trapon et al., 2013a, 2013b; Lozano-Cortés and Zapata, 2014a), there is little information about coral reproduction and demography in the Red Sea (Berumen et al., 2013). While there are a few accounts of inferred or observed spawning patterns from the Red Sea (Shlesinger and Loya, 1985; Shlesinger et al., 1998; Hanafy et al., 2010; Bouwmeester et al., 2011a, 2011b, 2015), published literature on coral recruitment in this region is restricted to the far northern area (Gulf of Aqaba) and is focused primarily on settlement in artificial plates (Glassom et al., 2004; Abelson et al., 2005; Glassom and Chadwick-Furman, 2006).

Bak and Meesters (1998); Meesters et al. (2001) and Vermeij and Bak (2002) used colony size-frequency data and a lognormal size

\footnotetext{
* Corresponding author at: Red Sea Research Center, King Abdullah University of Science and Technology, Thuwal, Jeddah, 23955-6900, Saudi Arabia.

E-mail address: diegoflc@gmail.com (D.F. Lozano-Cortés).
}

distribution model of corals in the Caribbean Sea to quantify character- 59 istics of the coral populations (e.g., coefficient of variation, mode, and 60 skewness) and related these measurements to reef environment 61 (e.g., degradation level). These authors used skewness to compare the 62 proportion of small vs. large colonies as a proxy for the establishment of 63 new juvenile corals in reefs with different degrees of pollution. They 64 found differences in these size-frequency variables among- and within- 65 species in different reef localities and suggested that these characters 66 could provide a tool to more generally estimate the response of coral pop- 67 ulations to changes in the environment. These studies reported a relation- 68 ship between negative values of skewness and more degraded reefs. 69 Similar results were found by Crabbe (2009) and Lozano-Cortés and 70 Zapata (2014b) in other Caribbean coral reefs that had been impacted 71 by bleaching events and tourism (Hawkins et al., 1999), as well as by 72 Bauman et al. (2013) in reefs under extreme environmental conditions 73 (high temperature and salinity) in the Arabian Gulf.

The Red Sea is characterized by a latitudinal gradient in physico- 75 chemical variables such as salinity (42-37 psu), temperature (20-32 76 ${ }^{\circ} \mathrm{C}$ ), turbidity and primary productivity (low-high), creating distinct 77 habitats in the north-central region from the southern region (Raitsos 78 et al., 2011, 2013, Nanninga et al., 2014). The separation between 79 these zones occurs around $20^{\circ} \mathrm{N}$ where there is a notable shift in both 80 reef development patterns and oceanographic conditions (i.e., such as 81 a shift from clear and oligotrophic waters in the north-central region 82 to more turbid, warmer, nutrient-rich waters with less reef develop- 83 ment in the south [Roberts et al., 1992]). This north-south latitudinal 84 gradient is also strongly seasonal. For example, the water temperature 85 
changes from 26 to $20^{\circ} \mathrm{C}$ (summer-winter) in the north and from 32 to $28^{\circ} \mathrm{C}$ in the south. Similarly, Raitsos et al. (2013) documented a seasonal pattern for Chl- $a$ with the highest concentrations during the winter and lowest during the summer. These authors attributed this seasonality to processes of vertical mixing (north) and high-nutrient water intrusion (south) during winter months, and the occurrence of strong water stratification in summer time. This marked environmental shift has also been associated with changes in biological factors of reef organisms such as abundance, community composition, and richness, as well as restrictions in gene flow between regions (Roberts et al., 1992; Froukh and Kochzius, 2007; Nanninga et al., 2014; Sawall et al., 2014a; Giles et al., in press but see Robitzch et al., 2015). More recently, differences in zooplankton diversity and zooxanthellae density in corals have been documented along the aforementioned gradient (Pearman et al., 2014; Sawall et al., 2014b). Finally, directly inverse relationships have been reported elsewhere between juvenile coral density and fish density or algal cover (Box and Mumby, 2007; Mumby et al., 2007; Trapon et al., 2013a). Although herbivory and grazing are generally considered to be beneficial for reef health (Mumby et al., 2006; Mumby, 2009), grazing fishes may be a major source of juvenile coral mortality via incidental removal or predation while feeding (Penin et al., 2010; Doropoulos et al., 2012). On the other hand, negative interactions between algal cover and coral juvenile density are expected due to competition for space. As such, high algal cover is typically associated with low coral recruitment (Hughes et al., 2007; Mumby et al., 2007; Hoey et al., 2011).

In this study, we quantified the abundance and size of pocilloporid juvenile corals in nine coral reefs in the central and southern regions of the Saudi Arabian Red Sea. The studied reefs experience different oceanographic regimes and levels of disturbances, including biological variables such as density of grazing fishes and algal cover. By assessing the size-frequency distributions of juvenile populations, we aimed to explore the relationship, if any, between these demographic variables and reef conditions. As negatively skewed populations have been previously associated with less favorable environmental conditions, we expected to find more negative values in the southern Red Sea in comparison with the central region where coral populations are potentially under suboptimal conditions for development (e.g., reduced somatic growth and less successful reproduction). The Red Sea's natural environmental gradient represents an excellent opportunity to study the variation of juvenile colony size-frequency and its relationship with the reef environment.

\section{Materials and methods}

\subsection{Study sites and species}

A total of nine coral reefs (central and southern regions) were surveyed in the Saudi Arabian Red Sea spanning $670 \mathrm{~km}$ of coastline (Fig. 1 , Table 1 ). In the central region, six reefs (one inshore, three midshelf, and two offshore) near Thuwal and Al Lith were surveyed between October 2013 and May 2014. Both sampling months in our study can be considered to be in the Red Sea summer season (May is early summer while October is late summer). Published studies on coral recruitment in the Red Sea using artificial settlement plates (Glassom et al., 2004; Abelson et al., 2005; Glassom and Chadwick-Furman, 2006) have reported high abundance of pocilloporid recruits in comparison with other coral species, highlighting the suitability of this family for targeted coral recruitment studies. Spawning in Pocillopora in the Red Sea has been reported to occur at the end of May (Bouwmeester et al., 2011a, 2015) and growth rates for pocilloporids have been reported to be between 35 to $50 \mathrm{~mm}$ per year (Dullo, 2005). Corals that successfully recruited and survived to the juvenile stage were probably detected at our sampling sites despite the difference in sampling dates
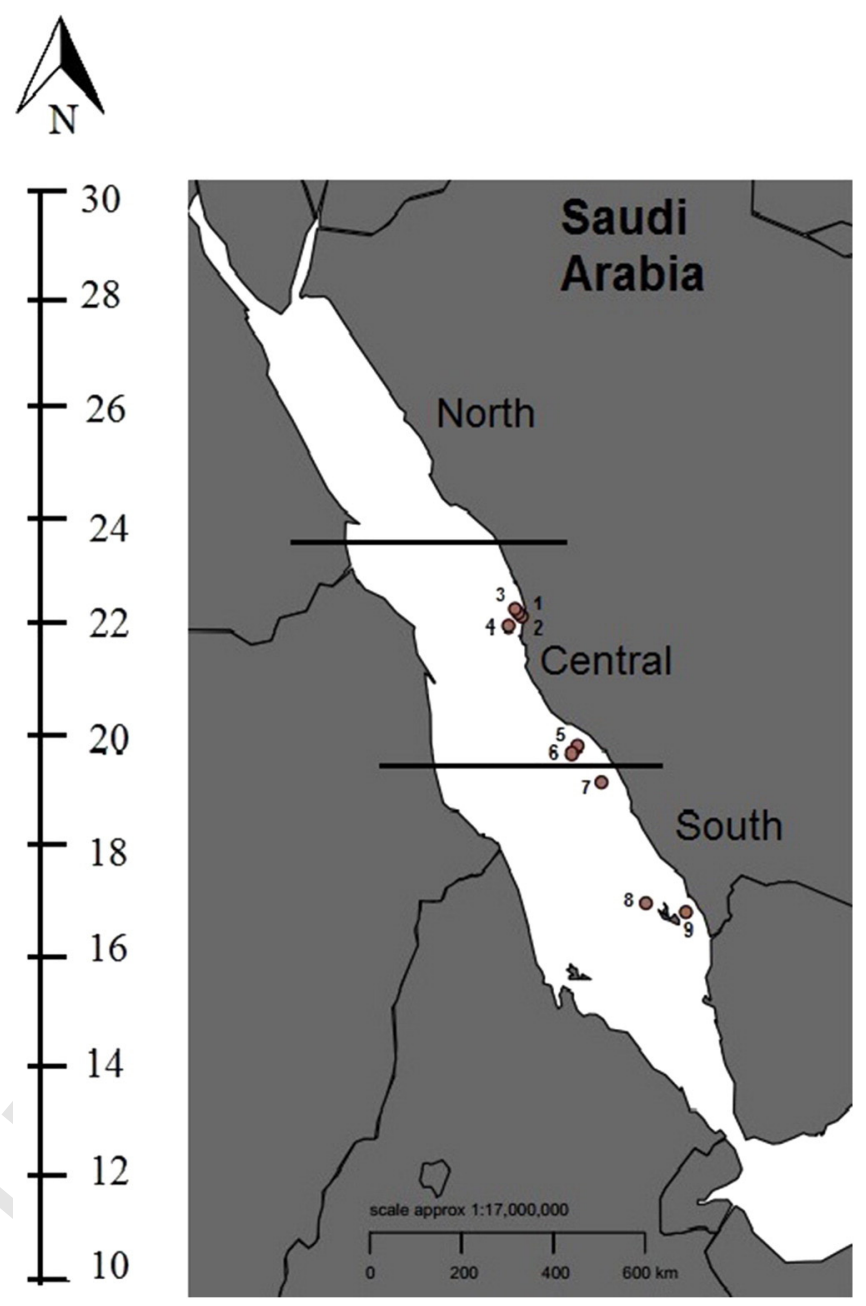

Fig. 1. Map of reefs surveyed (red circles) in the central and southern Red Sea, Saud Arabia. The axis in the left shows the latitude. The division of the basin into northern, central and southern Red Sea is done considering marked environmental and genetical shifts previously reported (e.g., Raitsos et al., 2013; Nanninga et al., 2014). Numbers indicate the nine studied reefs listed in the Table 1. (For interpretation of the references to color in this figure legend, the reader is referred to the web version of this article.)
In the southern region, three coral reefs (one mid-shelf and two off- 148 shore) were sampled in the Farasan Banks and Farasan Islands area in 149 February 2014. Some reefs located in the central region were affected 150 by a major bleaching event in the summer of 2010. This bleaching 151 event affected between 14 and 74\% of the coral colonies in this region 152 (Furby et al., 2013; Pineda et al., 2013). In the aforementioned bleaching 153 events, pocilloporids exhibited bleaching based on their proximity to 154 shore and depth, ranging from 0.5 to $0.7 \%$ in deeper, offshore waters 155 to $60.9-75.0 \%$ in shallow, inshore areas. On the other hand, Riegl et al. 156 (2012) inferred (from the state of coral communities) that the Farasan 157 Islands were impacted by a bleaching event more than a decade ago, 158 and regional crown-of-thorns starfish outbreaks were observed in 159 2006 (Riegl et al., 2013), but it is unknown if our specific study reefs 160 were affected (Table 1 ).

Our study targeted pocilloporid coral species, e.g., Pocillopora 162 damicornis, Pocillopora verrucosa, Seriatopora hystrix, Stylophora 163 pistillata. These species utilize a brooding reproductive strategy and 164 tend to be among the most commonly observed new recruits in coral 165 communities in the Red Sea (cite examples from above). As such, the 166 pocilloporids are an ideal study group in this region. While we acknowl- 167 edge major taxonomic limitations associated with in-situ identification 168 of some pocilloporid species (e.g., Keshavmurthy et al., 2013), our 169 
t1.1 Table 1

t1.2 Juvenile coral abundance, fish density and algal cover for nine coral reefs in the Saudi Arabian Red Sea.

\begin{tabular}{|c|c|c|c|c|c|c|c|c|c|}
\hline Reef location & $\begin{array}{l}\text { Type of } \\
\text { reef }\end{array}$ & $\mathrm{N}$ & $\begin{array}{l}\text { Mean coral size } \\
(\mathrm{mm})\end{array}$ & $\begin{array}{l}\text { Coral size } \\
\text { range }(\mathrm{mm})\end{array}$ & $\begin{array}{l}\text { Coral denstity } \\
\text { (ind } / \mathrm{m} 2 \text { ) }\end{array}$ & $\begin{array}{l}\text { Bleaching } \\
\text { history }\end{array}$ & Skewness & $\begin{array}{l}\text { Parrotfish density } \\
\text { (ind } / \mathrm{m} 2 \text { ) }\end{array}$ & $\begin{array}{l}\text { Macroalgae cover } \\
(\%)\end{array}$ \\
\hline \multicolumn{10}{|l|}{ Central } \\
\hline 1. Fsar & Inshore & 44 & $31.03 \pm 10.02$ & $15-50$ & $2.93 \pm 1.03$ & 2010 & -0.2148 & $0.11 \pm 0.04(4)$ & $3.50 \pm 4.43(4)$ \\
\hline 2. Al Fahal & Midshelf & 54 & $31.81 \pm 9.80$ & $15-50$ & $3.56 \pm 1.88$ & 2010 & -0.1982 & $0.06 \pm 0.01(4)$ & $1.00 \pm 1.15(5)$ \\
\hline 3. Abu Madafi & Offshore & 66 & $26.86 \pm 10.12$ & $6-50$ & $4.40 \pm 3.92$ & 2010 & -0.9914 & $0.02 \pm 0.02(5)$ & $0.50 \pm 0.84(6)^{\mathrm{c}}$ \\
\hline 4. Sahib Kabir & Offshore & 48 & $26.02 \pm 10.09$ & $5-46$ & $3.20 \pm 2.21$ & $2010^{\mathrm{a}}$ & -0.7010 & - & - \\
\hline 5. Manila Bay & Midshelf & 58 & $31.63 \pm 9.65$ & $16-50$ & $3.87 \pm 1.88$ & No data & -0.9510 & $0.01 \pm 0.01(3)$ & - \\
\hline 6. Central Reef & Midshelf & 58 & $31.55 \pm 10.34$ & $14-50$ & $3.87 \pm 1.25$ & No data & -0.1082 & $0.01 \pm 0.01$ & $0.00 \pm 0.00(3)^{c}$ \\
\hline \multicolumn{10}{|l|}{ Southern } \\
\hline 7. Sahib Daqua & Offshore & 31 & $30.15 \pm 11.58$ & $14-50$ & $2.07 \pm 1.39$ & No data & 0.2066 & $0.02 \pm 0.01(6)$ & $0.00 \pm 0.00(6)^{\mathrm{c}}$ \\
\hline 8. Dhi Dahaya & Midshelf & 32 & $27.27 \pm 9.61$ & $5-49$ & $2.13 \pm 1.51$ & No data ${ }^{b}$ & -1.1088 & $0.42 \pm 0.08(5)$ & $19.33 \pm 5.60(6)^{\mathrm{C}}$ \\
\hline 9. Zahrat Durakah & Offshore & 63 & $28.96 \pm 10.46$ & $6-50$ & $4.20 \pm 2.70$ & No datab & -0.3990 & $0.27 \pm 0.10$ & $2.78 \pm 2.03(3)^{c}$ \\
\hline
\end{tabular}

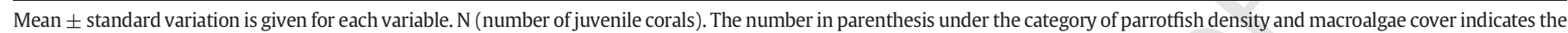
number of transects surveyed in a given reef.

a Furby et al. (2013) found that the nearest two offshore reefs were affected by the 2010 bleaching event, so we assume that this reef was similarly affected.

b Riegl et al. (2012) inferred that bleaching occurred in the Farasan Islands, but it is unknown if bleaching affected these specific reefs.

c (Bouwmeester, unpublished data).

analyses only consider family-level data and are thus not impacted by species-level ambiguities.

\subsection{Juvenile coral sampling}

Surveys of juvenile pocilloporid corals were conducted on the exposed side of all sites at a $5 \mathrm{~m}$ depth. During the sampling, we followed the criteria proposed by Glynn et al. (1996) to differentiate between sexually originated coral recruits from remnant coral colonies. Juvenile corals ( $\leq 50 \mathrm{~mm}$ maximum diameter) were surveyed systematically within 15 replicate $1 \mathrm{~m}^{2}$ quadrats placed haphazardly on the reef. Each quadrat was divided into a $4 \times 4$ grid and the resulting 16 subquadrats $\left(0.0625 \mathrm{~m}^{2}\right.$ each) were each carefully inspected to maximize the detection of juveniles. The maximum and minimum diameter of each colony was measured at the base of the colony to the nearest $\mathrm{mm}$ using calipers. The colony area $\left(\mathrm{cm}^{2}\right)$ was estimated using the formula for a half-sphere (Area $=2 \times[$ (maximum diameter $/ 2 \times$ minimum diameter $/ 2) \times \pi])$. These area data were logarithmically transformed and the skewness ( $\mathrm{g} 1$ ) was calculated for each coral reef (Meesters et al., 2001).

\subsection{Fish density and algal cover}

To determine the relationship between the abundance and size of juvenile corals with fish density, visual censuses of parrotfishes were carried out along a belt transect $50 \mathrm{~m} \times 4 \mathrm{~m}$ (between three to six replicates) at 5-10 $\mathrm{m}$ depth, parallel and adjacent to the area where benthic surveys were conducted. Parrotfishes were selected for this study because their feeding activity has been documented as beneficial for coral recruitment and growth (Mumby, 2009). All of the sampling (corals, fish, and algae) was done simultaneously, but for logistical reasons and to reduce the disturbance on the fish community resulting from the divers sampling corals and algae, in some occasions the fish censuses were done deeper than $5 \mathrm{~m}$ depth. During the censuses all parrotfishes were counted and the mean density was estimated from the replicates per site. To estimate macroalgae cover, line intercept transects (10 m long transect, between 3 and 6 replicates per site) were done in the same area as the juvenile coral sampling along the $5 \mathrm{~m}$ contour and at as many of the surveyed coral reefs as possible (seven out of nine reefs, 33 replicates in total; Table 1 ).

\subsection{Data analysis}

Non-parametric tests were used for all analyses as the data did not meet the assumptions of normal distribution and homoscedasticity.
The analyses were performed using the computer software Statistica 210 7. Juvenile coral colony sizes and densities were compared among the 211 nine reefs using a Kruskal-Wallis ANOVA (K-W). Unequal HSD Tukey 212 post-hoc tests were used when significant differences were detected 213 in the ANOVA. Due to the sample sizes, data for both variables were 214 pooled into central and southern categories to explore differences be- 215 tween regions. Once the data was grouped, the two regions were com- 216 pared using a non-parametric Mann-Whitney t-test (M-W). Following 217 Bak and Meesters (1998), the projected surface area of each colony was 218 estimated and size-frequency distributions were constructed from 219 these data. As size frequencies are more informative when analyzed as 220 geometric functions, juvenile colony area data were log-transformed 221 to facilitate the comparison of skewness between regions (see Vermeij 222 and Bak, 2002). A Chi-square test was carried out to compare the size- 223 frequency distribution between the two regions (central-southern). 224

Fish density and algal cover data were also grouped into central and 225 southern regions as mentioned above for the juvenile corals and com- 226 pared using a Mann-Whitney test. Finally, Spearman correlations 227 were used to explore the relationship between the variables studied 228 (juvenile density vs fish density, juvenile density vs algal cover, and 229 fish density vs algal cover) using the information obtained from individ- 230 ual reefs.

\section{Results}

\subsection{Juvenile corals}

Juvenile corals $(\mathrm{N}=454)$ ranged in size from 0.5 to $50 \mathrm{~mm}$ maxi- 234 mum diameter with an overall mean diameter of $29.43 \mathrm{~mm}(\mathrm{SD} \pm 235$ $10.24 \mathrm{~mm}$; Table 1). Statistical differences were detected in the size of 236 juvenile corals among reefs $\left(\mathrm{K}-\mathrm{W}, \mathrm{H}_{(8, \mathrm{~N}}=454\right)=19.067, \mathrm{p}=237$ 0.0145 ), with smaller colonies in the offshore central reefs (Abu Madafi 238 and Shib Kabir, $\mathrm{M}-\mathrm{W}, \mathrm{U}=14,169.50, \mathrm{p}=0.000973$; Table 1 ), but not 239 between regions ( $\mathrm{M}-\mathrm{W}, \mathrm{U}=18,847.00, \mathrm{p}=0.146)$. Juvenile coral den- 240 sity (mean $\pm \mathrm{SD}$ ) differed significantly among reefs $\left(\mathrm{W}, \mathrm{H}_{(8, \mathrm{~N}=135)}=241\right.$ $18.426, \mathrm{p}=0.0183$ ), with lower densities existing in the southern reefs 242 (Shib Daqua and Dhi Dahaya; Table 1) and between regions (M-W, $\mathrm{U}=243$ $1545.500, \mathrm{p}=0.025)$ with values higher in the central Red Sea $(3.64 \pm 244$ 2.23 juveniles $\left.\mathrm{m}^{2}\right)$ than those found in the southern Red Sea $(2.84 \pm 245$ 2.16 juveniles $\mathrm{m}^{2}$, Fig. 2 ).

The size-frequency distribution per reef shows a higher abundance 247 of smaller individuals in the central Red Sea than in the southern Red 248 Sea (Fig. 3). However, they were not statistically different (Chi-square 249 $\mathrm{p}=19.675, \alpha=0.05$ ). Reefs in both regions showed negative values 250 of skewness (Table 1). It is notable that the more negatively-skewed 251 size distributions came from reefs in the central region that were 252 
recently affected by the aforementioned bleaching event while the reef from the southern region is the one with the highest parrotfish density and macroalgae cover.

\subsection{Parrotfish density and macroalgal cover}

Five species of parrotfish were recorded during the fish censuses (Chlorurus gibbus, Chlorurus sordidus, Scarus ferrugineus, Scarus Niger, Scarus rubroviolaceus). The comparison between the two regions for parrotfish density and macroalgal cover reveals a marked difference. The southern region possesses high values of fish density and algal cover while the central region shows an opposite pattern with lower values (Fig. 2). These differences were statistically significant for the parrotfish density ( $M-W, U=64.50, p=0.016)$ but not for the algae cover $(M-W, U=99.00, p=0.79)$. This pattern of higher values in the southern region for fish density and algal cover is opposite to what we found for juvenile coral density. Finally, the only significant correlation was between parrotfish density and macroalgae cover showing a positive relationship along the central and southern Saudi Arabian Red Sea (Spearman, df $=27, \mathrm{R}=0.39$, $\mathrm{p}=0.035$ ).

\section{Discussion}

We found that the pocilloporid juvenile coral size-frequency distribution, independent of the region, was more negatively skewed for reefs under unfavorable environmental conditions (i.e., recently bleached) or under ongoing biological stress (i.e., high parrotfish density and algal cover). Coral size-frequency distribution has been used as a proxy for reef conditions and past disturbances (Bak and Meesters, 1998; Meesters et al., 2001; Vermeij and Meesters, 2002; Crabbe, 2009; Bauman et al., 2013; Lozano-Cortés and Zapata, 2014b). These
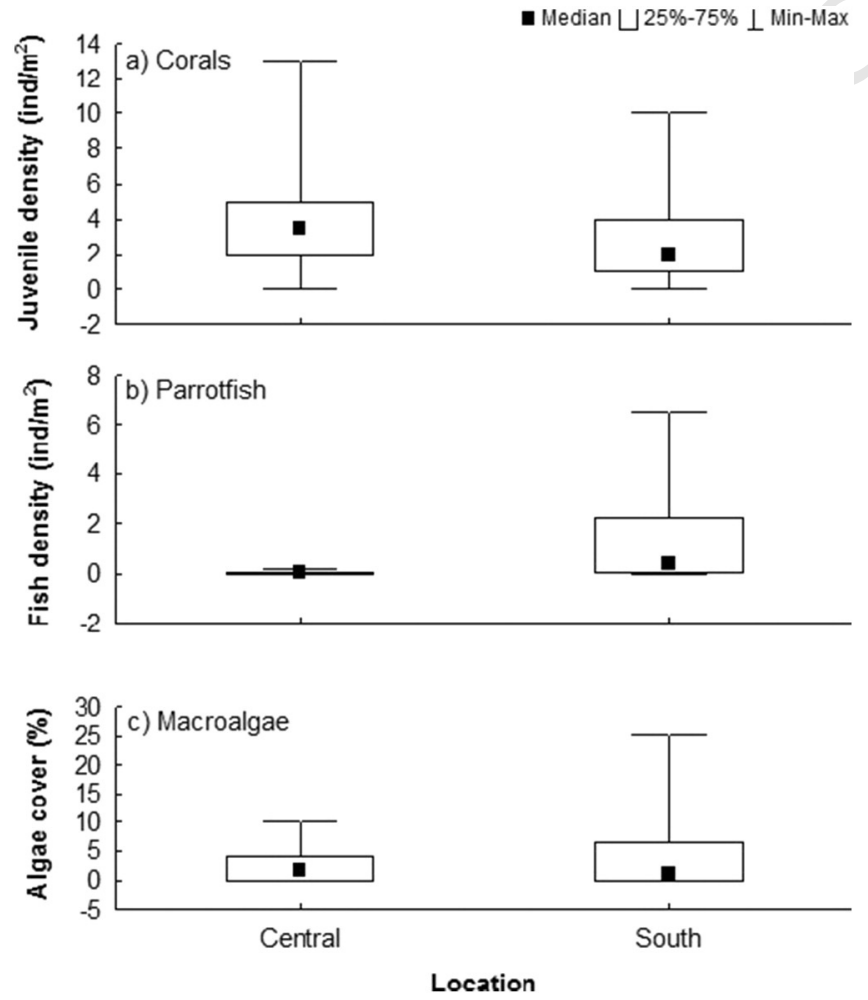

Fig. 2. Juvenile pocilloporid density (a), parrotfish density (b) and algal cover (c) for nine coral reefs grouped into two regions (central and southern) of the Saudi Arabian Red Sea. Each reef was surveyed using quadrats $\left(1 \mathrm{~m}^{2}\right)$ for (a), visual censuses in belt transects $(50 \mathrm{~m} \times 4 \mathrm{~m})$ for $(\mathrm{b})$ and, line intercept transects $(10 \mathrm{~m})$ for $(\mathrm{c})$. Differences between the two regions are statistically significant for (a) and (b), but not (c). previous studies have concluded that negatively skewed corals size dis- 281 tributions are associated with degraded reefs and more positively 282 skewed values with healthier ecosystems. In this study, we compared 283 the size structure of juvenile pocilloporid corals between two regions 284 under contrasting oceanographic conditions in the Red Sea. The central 285 region is characterized by oligotrophic water, with temperature ranges 286 of $24^{\circ} \mathrm{C}-30^{\circ} \mathrm{C}$ and salinities around $39-41 \mathrm{psu}$. In contrast, the southern 287 region is less oligotrophic and temperatures $26^{\circ} \mathrm{C}-32{ }^{\circ} \mathrm{C}$ and salinities 288 between 36.5 and 38.5 psu (Sofianos and Johns, 2003; Raitsos et al., 289 2013). Contrary to our expectations, the results did not show any signif- 290 icant juvenile size structure (number of individuals within a given size 291 category) differences between regions. However, differences in juvenile 292 coral size (mean colony size) and density (number of juveniles by area) 293 among reefs with varying stress regimes were observed, suggesting that 294 some variables of colony frequency-distribution in coral are site- 295 specific. This study provides novel data on juvenile corals in the Red 296 Sea that would be essential for further understanding of what is driving 297 the unexplained patterns observed here. The juvenile coral density 298 values reported here are lower than two previous studies in Saudi 299 coral reefs. Jessen et al. (2014) reported a density of 110 juveniles $\mathrm{m}^{2} 300$ in settlement plates from a reef in the central region, while Riegl et al. 301 $(2012,2013)$ found 13 juveniles $\mathrm{m}^{2}$ on natural substrata from reefs in 302 the southern region. These differences are mainly attributed to the 303 fact that these authors considered all scleractinia together while in 304 this study only pocilloporids data were taken into account. Also, differ- 305 ences in sampling seasons among studies (affecting post-settlement 306 survival; Glassom et al., 2004; Kuo and Soong, 2010) and the variability 307 in settlement rates on plates versus natural substrata (e.g., Salinas-de- 308 León et al., 2011) will result in different juvenile density estimates. 309

The unexpected lack of differences in size-frequency distribution be- 310 tween regions could be attributed to two possible causes. The first is a 311 lack of statistical power due to insufficient sampling to detect differ- 312 ences between regions. This is suggested by the amplitude of the vari- 313 ance in the colony size data, which might have obscured the effect 314 size of the environmental conditions. Also, care should be taken with 315 the nature of the data (i.e., unbalanced design and few sampled sites). 316 The difficulty of detecting the smallest recruits $(<20 \mathrm{~mm})$ by the 317 naked eye during underwater observation may introduce a statistical 318 artifact producing proportional size-frequency curves that would look 319 identical when fitted. The second potential cause to consider is the sen- 320 sitivity of pocilloporid corals to disturbances (physicochemical or bio- 321 logical). Previous studies have utilized skewness values to identify the 322 level of sensitivity of particular families to changes in environmental 323 conditions (e.g., Meesters et al., 2001). Coral families that show positive 324 skewness values in healthy reefs and negative skewness values in de- 325 graded reefs are inferred to be sensitive to changes, while families that 326 do not show a skewness difference between healthy and degraded 327 reefs are inferred to be insensitive to environmental change 328 (e.g., Meesters et al., 2001). It is possible that our sampling did not 329 find a difference in skewness values because some frequency distribu- 330 tion parameters are species-specific and Red Sea pocilloporids may be 331 robust to these environmental gradients. Similarly, the primary aim of 332 this study was to collect juvenile coral data for the main Red Sea, as 333 there were no data previously available. This lack of data limits our abil- 334 ity to compare with historical conditions or other places but we offer 335 some suggestions for future studies to more thoroughly investigate. $\quad 336$

As the presence of algae attracts herbivorous fishes that can cause 337 juvenile coral mortality via incidental grazing (Bak and Engel, 1979), a 338 considerable amount of juvenile coral mortality is expected under con- 339 ditions of high algal cover and high densities of parrotfishes (Penin et al., 340 2010; Trapon et al., 2013a). This may be occurring in the southern 341 region where the low density of juvenile corals compared with the cen- 342 tral region can be associated with the ongoing conditions of algal cover 343 and parrotfish density (5-fold and 3-fold higher than reefs in the central 344 region respectively; Fig. 2). For the reefs in the central region, where 345 algal cover and parrotfish densities were moderately low in comparison 346 

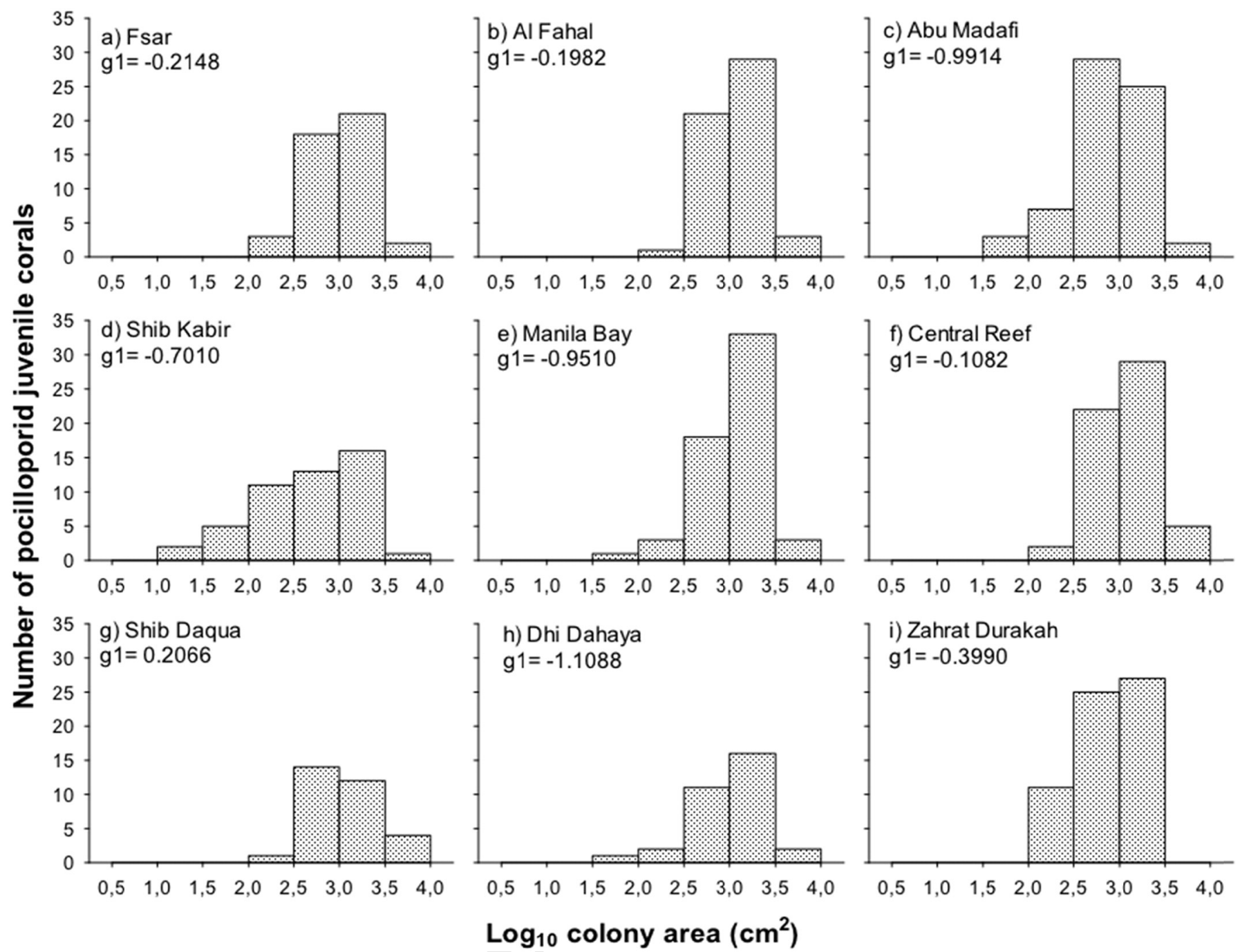

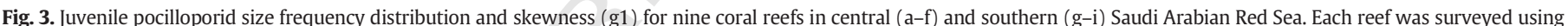

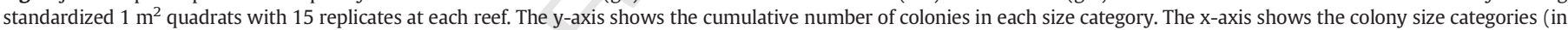
$0.5 \mathrm{~cm}^{2}$ bins).

with the southern region, the negatively skewed results may be attributed to past disturbances. These reefs were affected by a major bleaching event three years prior to our study (summer 2010: Furby et al., 2013; Pineda et al., 2013). Bleaching events not only can affect coral size distributions (McClanahan et al., 2008) but also affect the biomass of herbivorous fishes. For instance, Khalil et al. (2013) reported a reduction of up to 2 orders of magnitude of parrotfishes and surgeonfishes in this region after the bleaching event. Even though the current low abundance of parrotfishes in the central region (in comparison with the southern region) may be an indirect effect of this previous disturbance, it may be related to the persistent low levels of algal cover in this area (i.e., due to the positive correlation between parrotfish and macroalgae). In this study and others carried out in the central Red Sea, the macroalgal cover has varied between 3.5\% to undetectable levels (Table 1; Jessen et al., 2013) contrasting with the values of up to $19 \%$ found in the southern region (Farasan Islands; Table 1). Nevertheless, from our results we can conclude that algal cover and fish density are less important than other potential factors including past bleaching events in the size structure distribution of the juvenile pocilloporid corals studied.

The Red Sea latitudinal environmental gradient is characterized by an increase of primary productivity and turbidity towards the south, probably as a consequence of the intrusion of nutrient-rich waters from the Gulf of Aden, with a drastically habitat shift around the 19- $20^{\circ} \mathrm{N}$. This shift coincides with the area of eddy formations in the Red 371 Sea and has been proposed as an environmental barrier for dispersal 372 and genetic flow in the southern region (Raitsos et al., 2011, 2013; 373 Nanninga et al., 2014; Giles et al., in press). Nanninga et al. (2014) 374 using Chl- $a$ as a proxy for the environmental gradient found that the 375 patterns of gene flow in the anemonefish Amphiprion bicinctus followed 376 a stepping-stone model along the northern and central Red Sea and it 377 was disrupted around the aforementioned habitat shift. Giles et al. (in 378 press) found that the genetic isolation of the sponge Stylissa carteri in 379 the southern Red Sea was also correlated with this environmental het- 380 erogeneity. Similarly, simulations of coral larvae dispersal in this area 381 have suggested the occurrence of a barrier to northward dispersal 382 (Fine et al., 2013). Numerous other factors that may generate very 383 small-scale differences were not measured in this study, such as nutri- 384 ents, temperature, and light regimes, but could influence local size 385 structure as well. Future studies aiming to resolve the roles of all possi- 386 ble factors will have to carefully consider and measure these numerous 387 variables. The Red Sea coral reefs have developed under unique condi- 388 tions of salinity, temperature and isolation (Racault et al., 2015). These 389 conditions may have led to unique ecological adaptations within the 390 Red Sea and resultant differences in response to environmental stresses 391 compared to populations in other seas (Voolstra et al., 2015). Our data, 392 despite the caveats mentioned here, suggest that the Red Sea may func- 393 tion differently than other systems. Nonetheless, this study cannot 394 
establish the causes of the patterns observed regarding the relationship between herbivorous fish and juvenile corals. Future studies should consider differences in the feeding ecology of Red Sea herbivores and the potential occurrence of mechanisms in the corals to avoid accidental predation more effectively than non-Red Sea corals. Our findings suggest that size-frequency distributions of juvenile pocilloporid corals are not sensitive to changes in biological or oceanographic factors that can present moderate stress conditions for the reef. Herein juvenile size-frequencies were not detected to act as a proxy for these potential stressors. A caveat in this study is the absence of data to compare to a "healthy" reef or prior to the bleaching event under "regular" conditions. However, the data presented here serve as an important starting point for monitoring future changes in the reef communities in these regions as a result of upcoming potential impacts.

\section{Submission declaration and verification}

The authors have declared that the work described in this paper has not been published previously and it is not under consideration for publication elsewhere. All the authors approved the final version of this paper and its submission to Marine Environmental Research.

\section{Contributors}

Conceived and designed the experiments: DLC MLB. Performed the experiments: DLC. Analyzed the data: DLC. Contributed reagents/materials/analysis tools: MLB DLC. Wrote the paper: DLC MLB.

\section{Conflict of interest}

The authors have declared that no competing interests exist.

\section{Acknowledgments}

This work was supported in part by baseline funding from King Abdullah University of Science and Technology (KAUST) to MLB, with logistical support from the KAUST Coastal and Marine Resources Core Lab and the crew of the R/V Thuwal. We thank the members of the Reef Ecology Lab at KAUST, especially Jessica Bouwmeester, Remy Gatins, Maha Khalil, Alex Kattan, May Roberts, and Marcela HerreraSarrias, as well as Eva Salas (University of California Santa Cruz) and Océane Salles (Université de Perpignan) for their help in data collection. Special thanks to May Roberts for her help with Fig. 1. Finally we thank Emily Giles (Universidad Austral de Chile) and Sarah Almahdali (KAUST) for their comments on the first draft of this manuscript.

\section{References}

Abelson, A., Olinky, R., Gaines, S., 2005. Coral recruitment to the reefs of Eilat, Red Sea: temporal and spatial variation and possible effects of anthropogenic disturbances. Mar. Pollut. Bull. 50, 576-582.

Babcock, R., Baird, A., Piromvaragorn, S., Thomson, D., Willis, B., 2003. Identification of scleractinian coral recruits from Indo-Pacific reefs. Zool. Stud. 42, 211-226.

Bak, R.P., Engel, M.S., 1979. Distribution, abundance and survival of juvenile hermatypic corals (Scleractinia) and the importance of life history strategies in the parent coral community. Mar. Biol. 54, 341-352.

Bak, R.P., Meesters, E.H., 1998. Coral population structure: the hidden information of colony size-frequency distributions. Mar. Ecol. Prog. Ser. 162, 301-306.

Bauman, A.G., Pratchett, M.S., Baird, A.H., Riegl, B., Heron, S.F., Feary, D.A., 2013. Variation in the size structure of corals is related to environmental extremes in the Persian Gulf. Mar. Environ. Res. 84, 43-50.

Berumen, M.L., Hoey, A.S., Bass, W.H., Bouwmeester, J., Catania, D., Cochran, J.E., Khalil, M.T., Miyake, S., Mughal, M.R., Spaet, J.L., Saenz-Agudelo, P., 2013. The status of coral reef ecology research in the Red Sea. Coral Reefs 32, 737-748.

Bouwmeester, J., Khalil, M.T., De La Torre, P., Berumen, M.L., 2011a. Daytime broadcast spawning of Pocillopora verrucosa on coral reefs of the central Red Sea. Galaxea: J. Coral Reef Stud. 13, 23-24.

Bouwmeester, J., Khalil, M.T., De La Torre, P., Berumen, M.L., 2011b. Synchronous spawning of Acropora in the Red Sea. Coral Reefs 30, 1011. http://dx.doi.org/10. 1007/s00338-011-0796-5.
Bouwmeester, J., Baird, A.H., Chen, G.J., Guest, J.R., Vicentuan, K.C., Berumen, M.L., 2015. 455 Multi-species spawning synchrony within scleractinian coral assemblages in the 456 Red Sea. Coral Reefs 34, 65-77. http://dx.doi.org/10.1007/s00338-014-1214-6. 457

Box, S.J., Mumby, P.J., 2007. The effect of macroalgal competition on the growth and sur- 458 vival of juvenile Caribbean corals. Mar. Ecol. Prog. Ser. 342, 139-149. 459

Burt, J., Bartholomew, A., Bauman, A., Saif, A., Sale, P.F., 2009. Coral recruitment and early 460 benthic community development on several materials used in the construction of ar- 461 tificial reefs and breakwaters. J. Exp. Mar. Biol. Ecol. 373, 72-78.

Caley, M.J., Carr, M.H., Hixon, M.A., Hughes, T.P., Jones, G.P., Menge, B.A., 1996. Recruit- 463 ment and the local dynamics of open marine populations. Annu. Rev. Ecol. Evol. 464 Syst. 27, 477-500 cate coral resilience on the fringing reefs of North Jamaica. Mar. Environ. Res. 67, 467 189-198. http://dx.doi.org/10.1016/j.marenvres.2009.01.003.

Doropoulos, C., Ward, S., Marshell, A., Diaz-Pulido, G., Mumby, PJ., 2012. Interactions 469 among chronic and acute impacts on coral recruits: the importance of size-escape 470 thresholds. Ecology 93, 2131-2138.

Dullo, W.C., 2005. Coral growth and reef growth: a brief review. Facies 51, 33-48. 472

Dunstan, P.K., Johnson, C.R., 1998. Spatio-temporal variation in coral recruitment at differ- 473 ent scales on Heron Reef, southern Great Barrier Reef. Coral Reefs 17, 71-81. 474

Fine, M., Gildor, H., Genin, A., 2013. A coral reef refuge in the Red Sea. Glob. Chang. Biol. 475 19, 3640-3647.

Froukh, T., Kochzius, M., 2007. Genetic population structure of the endemic fourline 477 wrasse (Larabicus quadrilineatus) suggests limited larval dispersal distances in the 478 Red Sea. Mol. Ecol. 16, 1359-1367.

Furby, KA Bouwmeester, J, Berumen, ML 2013. Susceptibility of central Red Sea corals during a major bleaching event. Coral Reefs 32, 505-513. 481

(in press)Giles, E.C., Saenz-Agudelo, P., Hussey, N.E., Ravasi, T., Berumen, M.L., 2015. Ex- 482 ploring seascape genetics and kinship in the reef sponge Stylissa carteri in the Red 483 Sea. Ecol. Evol.

Glassom, D., Chadwick-Furman, N.E., 2006. Recruitment, growth and mortality of juvenile 485 corals at Eilat, Northern Red Sea. Mar. Ecol. Prog. Ser. 318, 111-122. 486

Glassom, D., Zakai, D., Chadwick-Furman, N.E., 2004. Coral recruitment: a spatio-temporal 487 analysis along the coastline of Eilat, northern Red Sea. Mar. Biol. 144, 641-651. 488

Glynn, P.W., Colley, S.B., Gassman, N.J., Black, K., Cortés, J., Maté, J.L., 1996. Reef coral re- 489 production in the eastern Pacific: Costa Rica, Panama, and Galapagos Islands 490 (Ecuador). Agariciidae (Pavona gigantea and Gardineroseris planulata). Mar. Biol. 491 125, 579-601 (1996).

Hanafy, M.H., Aamer, M.A., Habib, A.B., Baird, A.H., 2010. Synchronous reproduction of 493 corals in the Red Sea. Coral Reefs 29, 119-124. 494

Hawkins, J.P., Roberts, C.M., VantHof, T., deMeyer, K., Tratalos, J., Aldam, C., 1999. Effects of 495 recreational scuba diving on Caribbean coral and fish communities. Conserv. Biol. 13, 496 888-897.

Hoey, A.S., Pratchett, M.S., Cvitanovic, C., 2011. High macroalgal cover and low coral re- 498 cruitment undermines the potential resilience of the world's southernmost coral 499 reef assemblages. PLoS One 6 (10), e25824. http://dx.doi.org/10.1371/journal.pone. 500 0025824.

Hughes, T.P., Rodrigues, M.J., Bellwood, D.R., Ceccarelli, D., Hoegh-Guldberg, O., McCook, 502 L., Moltschaniwskyj, N., Pratchett, M., 2007. Phase shifts, herbivory, and the resilience 503 of coral reefs to climate change. Curr. Biol. 17, 1-6. http://dx.doi.org/10.1016/j.cub. 504 2006.12.049.

Jessen, C., Roder, C., Villa Lizcano, J.F., Voolstra, C.R., Wild, C., 2013. In-situ effects of sim- 506 ulated overfishing and eutrophication on benthic coral reef algae growth, succession, 507 and composition in the Central Red Sea. PLoS One 8, e66992.

Jessen, C., Voolstra, C.R., Wild, C., 2014. In situ effects of simulated overfishing and eutro- 509 phication on settlement of benthic coral reef invertebrates in the Central Red Sea. 510 PeerJ 2, e339. http://dx.doi.org/10.7717/peerj.339.

Keshavmurthy, S., Yang, S.Y., Alamaru, A., Chuang, Y.Y., Pichon, M., Obura, D., Fontana, S., 512 De Palmas, S., Stefani, F., Benzoni, F., MacDonald, A., Noreen, A.M.E., Chen, C., Wallace, 513 C.C., Pillay, R.M., Denis, V., Amri, A.Y., Reimer, J.D., Mezaki, T., Sheppard, C., Loya, Y., 514 Abelson, A., Mohammed, M.S., Baker, A.C., Mostafavi, P.G., Suharsono, B.A., Chen, 515 C.A., 2013. DNA barcoding reveals the coral "laboratory-rat", Stylophora pistillata en- 516 compasses multiple identities. Sci. Rep. 3, 1520. http://dx.doi.org/10.1038/srep01520. 517

Khalil, M.T., Cochran, J.E.M., Berumen, M.L., 2013. The abundance of herbivorous fish on 518 an inshore Red Sea reef following a mass coral bleaching event. Environ. Biol. Fish 519 96, 1065-1072.

Kuo, K.M., Soong, K., 2010. Post-settlement survival of reef-coral juveniles in southern 521 Taiwan. Zool. Stud. 49, 724-734.

Lozano-Cortés, D.F., Zapata, F.A., 2014a. Invertebrate colonization on artificial substrates 523 in a coral reef at Gorgona Island, Colombian Pacific Ocean. Int. J.Trop. Biol. Conserv. 524 62 (Suppl. 1), 161-168.

Lozano-Cortés, D.F., Zapata, F.A., 2014b. Abundance and composition of juvenile 526 scleractinian corals on a fringing reef (little reef) in San Andres island Colombia. 527 Mar. Biol. Res. http://dx.doi.org/10.1080/17451000.2014.914222.

McClanahan, T.R., Ateweberhan, M., Omukoto, J., 2008. Long-term changes in coral colony 529 size distributions on Kenyan reefs under different management regimes and across 530 the 1998 bleaching event. Mar. Biol. 153, 755-768.

Meesters, E.H., Hilterman, M., Kardinaal, E., Keetman, M., de Vries, M., Bak, R.P.M., 2001. 532 Colony size-frequency distributions of scleractinian populations: spatial and interspe- 533 cific variation. Mar. Ecol. Prog. Ser. 209, 43-54.

Mumby, P.J., 2009. Herbivory versus corallivory: are parrotfish good or bad for Caribbean 535 coral reefs? Coral Reefs 28, 683-690.

Mumby, P.J., Dahlgren, C.P., Harborne, A.R., Kappel, C.V., Micheli, F., Brumbaugh, D.R., 537 Holmes, K.E., Mendes, J.M., Box, S., Broad, K., Sanchirico, J.N., Buch, K., Stoffle, R.W., 538 Gill, A.B., 2006. Fishing, trophic cascades, and the process of grazing on coral reefs. 539 Science $311,98-101$ 
Mumby, P.J., Harborne, A.R., Williams, J., Kappel, C.V., Brumbaugh, D.R., Micheli, F. Holmes, K.E., Dahlgren, C.P., Paris, C.B., Blackwell, P.G., 2007. Trophic cascade facilitates coral recruitment in a marine reserve. Proc. Natl. Acad. Sci. U. S. A. 104 8362-8367.

Nanninga, G., Mughal, M., Saenz-Agudelo, P., Manica, A., Berumen, M.L., 2014. Environmental gradients predict the genetic population structure of a coral reef fish in the Red Sea. Mol. Ecol. 23, 591-602.

Pearman, J.K., El-Sherbiny, M.M., Lanzén, A., Al-Aidaroos, A., Irigoien, X., 2014. Zooplankton diversity across three Red Sea reefs using pyrosequencing. Front. Mar. Sci. 1 00027. http://dx.doi.org/10.3389/fmars.2014.00027.

Penin, L., Michonneau, F., Baird, A.H., Connolly, S.R., Pratchett, M.S., Kayal, M., Adjeroud, M., 2010. Early post-settlement mortality and the structure of coral assemblages. Mar. Ecol. Prog. Ser. 408, 55-64.

Pineda, J., Starczak, V., Tarrant, A., Blythe, J., Davis, K., Farrar, T., Berumen, M.L., da Silva, J.C.B., 2013. Two spatial scales in a bleaching event: corals from the mildest and the most extreme thermal environments escape mortality. Limnol. Oceanogr. 58, 1531-1545.

Racault, M.-F., Raitsos, D.E., Berumen, M.L., Brewin, R.W.J., Platt, T., Sathyendranath, S. Hoteit, I., 2015. Phytoplankton phenology indices in coral reef ecosystems: application to ocean-colour observations in the Red Sea. Remote Sens. Environ. 160, 222-234. http://dx.doi.org/10.1016/j.rse.2015.01.019.

Raitsos, D.E., Hoteit, I., Prihartato, P.K., Chronis, T., Triantafyllou, G., Abualnaja, Y., 2011. Abrupt warming of the Red Sea. Geophys. Res. Lett. 38, L14601.

Raitsos, D.E., Pradhan, Y., Brewin, R.J.W., Stenchikov, G., Hoteit, I., 2013. Remote sensing the phytoplankton seasonal succession of the Red Sea. PLoS One 8, e64909.

Riegl, B.M., Bruckner, A.W., Rowlands, G.P., Purkis, S.J., Renaud, P., 2012. Red Sea coral reef trajectories over 2 decades suggest increasing community homogenization and decline in coral size. PLoS One 7, e38396. http://dx.doi.org/10.1371/journal.pone. 0038396.

Riegl, B.M., Berumen, M.L., Bruckner, A.W., 2013. Coral population trajectories, increased disturbance and management intervention: a sensitivity analysis. Ecol. Evol. 3 , 1050-1064. http://dx.doi.org/10.1002/ece3.519.

Roberts, C.M., Shepherd, A.R.D., Ormond, R.F.G., 1992. Large-scale variation in assemblage structure of Red Sea butterflyfishes and angelfishes. J. Biogeogr. 19, 239-250.

Robitzch V, Banguera-Hinestroza E, Sawall Y, Al-Sofyani A, Voolstra CR. 2015. Absence of genetic differentiation in the coral Pocillopora verrucosa along environmental gradients of the Saudi Arabian Red Sea Front. Mar. Sci. doi:10:3389/fmars.2015.00005.
Salinas-de-León, P., Costales-Carrera, A., Zeljkovic, S., Smith, D.J., Bell, J.J., 2011. 578 Scleractinian settlement patterns to natural cleared reef substrata and artificial settle- 579 ment panels on an Indonesian coral reef. Estuar. Coast. Shelf Sci. 93, 80-85.

Sawall, Y., Al-Sofyani, A., Banguera-Hinestroza, E., Voolstra, C.R., 2014a. Spatio-temporal 581 analyses of Symbiodinium physiology of the coral Pocillopora verrucosa along large- 582 scale nutrient and temperature gradients in the Red Sea. PLoS One 9, e103179. 583 http://dx.doi.org/10.1371/journal.pone.0103179.

Sawall, Y, Al-Sofyani, A, Kürten, B. Al-Aidaroos, A.M, Hoang, B.X, Marimuthu, N, 585 Khomayis, H.S., Sommer, U., Gharbawi, W.Y., Wahl, M., 2014b. Coral communities, 586 in contrast to fish communities, maintain a high assembly similarity along the large 587 latitudinal gradient along the Saudi Red Sea coast. J. Ecosyst. Ecogr. S4, 003. http:// 588 dx.doi.org/10.4172/2157-7625.S4-003. Shlesinger, Y., Loya, Y., 1985. Coral community reproductive patterns: Red Sea versus the 590 Great Barrier Reef. Science 228, 1333-1335

Shlesinger Y Goulet T.L, Loya, Y 1998. Reproductive patterns of scleractinian corals in 592 the northern Red Sea. Mar. Biol. 132, 691-701.

Sofianos, S.S., Johns, W.E., 2003. An oceanic general circulation model (OGCM) investiga- 594 tion of the Red Sea circulation, 1. Exchange between the Red Sea and the Indian 595 Ocean. J. Geophys. Res. 107, 3196. http://dx.doi.org/10.1029/2001JC001184. 596

Trapon, M.L., Pratchett, M.S., Hoey, A.S., 2013a. Spatial variation in abundance, size and 597 orientation of juvenile corals related to the biomass of parrotfishes on the Great Bar- 598 rier Reef, Australia. PLoS One 8, e57788. http://dx.doi.org/10.1371/journal.pone. 599 0057788.

Trapon, M.L., Pratchett, M.S., Adjeroud, M., Hoey, A.S., Baird, A.H., 2013b. Post-settlement 601 growth and mortality rates of juvenile scleractinian corals in Moorea, French Polyne- 602 sia versus Trunk Reef, Australia. Mar. Ecol. Prog. Ser. 488, 157-170. http://dx.doi.org/ 603 10.3354/meps10389.

Vermeij, M.J., Bak, R.P., 2002. Inferring demographic processes from population size struc- 605 ture in corals. Proceedings of the 9th International Coral Reef Symposium 5, 606 pp. 593-598.

Voolstra, C.R., Miller, D.J., Ragan, M.A., Hoffmann, A., Hoegh-Guldberg, O., Bourne, D., Ball, 608 E., Ying, H., Foret, S., Takahashi, S., Weynberg, K.D., van Oppen, M.J.H., Morrow, K., 609 Chan, C.X., Rosic, N., Leggat, W., Sprungala, S., Imelfort, M., Tyson, G.W., Kassahn, K., 610 Lundgren, P., Beeden, R., Ravasi, T., Berumen, M., Abel, E., Fyffe, T., 2015. RefuGe2020 611 consortium - using 'omics' approaches to explore the adaptability and resilience of 612 coral holobionts to environmental change. Front. Mar. Sci. 2, 68. http://dx.doi.org/ 613 10.3389/fmars.2015.00068. 